\title{
A Study on the Anomalies of Liver in the South Indian Cadavers
}

\author{
Estudio sobre las Anomalías del Hígado en Cadáveres del Sur de India
}

\author{
Satheesha Nayak B.
}

\begin{abstract}
NAYAK, B. S. A study on the anomalies of Liver in the South Indian cadavers. Int. J. Morphol., 31(2):658-661, 2013.
SUMMARY: Liver is the largest gland in the body and rarely shows variations in its lobes and fissures. We studied 55 Formalinfixed livers for occurrence of abnormal shape, lobes, fissures and position of gall bladder. In $60 \%$ of cases the liver was normal. $40 \%$ livers showed one or the other variations. Additional lobes were found in $9.09 \%$ of cases. Additional fissure was found in $1.81 \%$ of cases. Presence of dumbbell shaped caudate lobe and presence of large papillary process was noted in $1.81 \%$ cases each. In $1.81 \%$ cases the fissure for ligamentum teres was absent or situated on the anterior surface of the liver. In $1.81 \%$ of cases each the liver was either extremely long or extremely flat. In $18.18 \%$ of the cases, the gall bladder was short and its fundus did not project beyond the inferior border of the liver. These findings may be useful for surgeons and radiologists.
\end{abstract}

KEY WORDS: Liver; Gall bladder; Variation; Lobe; Fissure; Abnormal.

\section{INTRODUCTION}

Liver is the largest gland of the body. It is situated under the right dome of the diaphragm and mainly occupies the right hypochondriac and epigastric regions. It is divided into anatomical right and left lobes by the line of attachment of falciform ligament, fissure for ligamentum venosum and fissure for ligamentum teres. It has caudate and quadrate lobes as the parts of right anatomical lobe. The hilum of the liver or porta hepatis is situated on its visceral surface and it transmits the blood vessels and nerves of the liver. The fossa for gall bladder is situated on the inferior surface of the right lobe of the liver and the gall bladder is situated in it. The fundus of the gall bladder usually projects beyond the inferior border of the liver (Standring et al., 2005).

Hepatic imaging technique is usually performed to search for primary or metastatic liver diseases (Sahani \& Kalva, 2004). The major fissures are the important landmarks for interpreting the lobar anatomy and locating the liver lesions. In the era of imaging and minimallyinvasive approaches, it is very important on the part of both the radiologists and operating surgeons to have a thorough knowledge of the anatomy and the commonlyoccurring variations of this organ. Anatomists witness most of the variations of the lobes and fissures of the liver.
Although the segmental anatomy of the liver has been extensively researched, there are very few studies regarding the surface variations of the liver. Hence, we undertook this comprehensive study to observe and note the variations on the surface of the liver.

\section{MATERIAL AND METHOD}

Fifty-five formalin-fixed livers were used for this study. All these livers belonged to adults of unknown age and gender. All the livers were apparently normal and free from any disease. These livers were specifically observed for the changes in size, shape and for the presence of any abnormal lobes and fissures.

\section{RESULTS}

Among the 55 livers studied, 33 livers (60\%) were normal in their external appearance, number of lobes and fissures. However 22 livers (40\%) showed anomalies in lobes, fissures, shape or in the size of gall bladder. 
Additional lobes were seen in five livers (9.09\%). These additional lobes were small and were situated in the vicinity of the porta hepatis, caudate and quadrate lobes (Figs. 1 and 8). Additional fissure was found in one liver $(1.81 \%)$. This fissure separated the left lobe into two parts (Fig. 1). An abnormal, dumbbell like caudate lobe was found in one liver (1.81\%) (Fig. 6). The papillary process of the caudate lobe was very large in one liver $(1.81 \%)$ (Fig. 5). In ten livers (18.18\%) the gall bladder was short and its fundus did not project beyond the inferior border of the liver (Fig. 4). The fissure for ligamentum teres was absent in one liver (1.81\%) (Fig. 2) and it was on the anterior surface of the liver in one case (1.81\%) (Fig. 3). The left lobe was extremely elongated in one liver (1.81\%) (Fig. 7) and the liver was very flat in a single case (1.81\%) (Fig. 8). The Table I shows the abnormalities and number of livers and the percentage of cases in which the abnormalities were found.

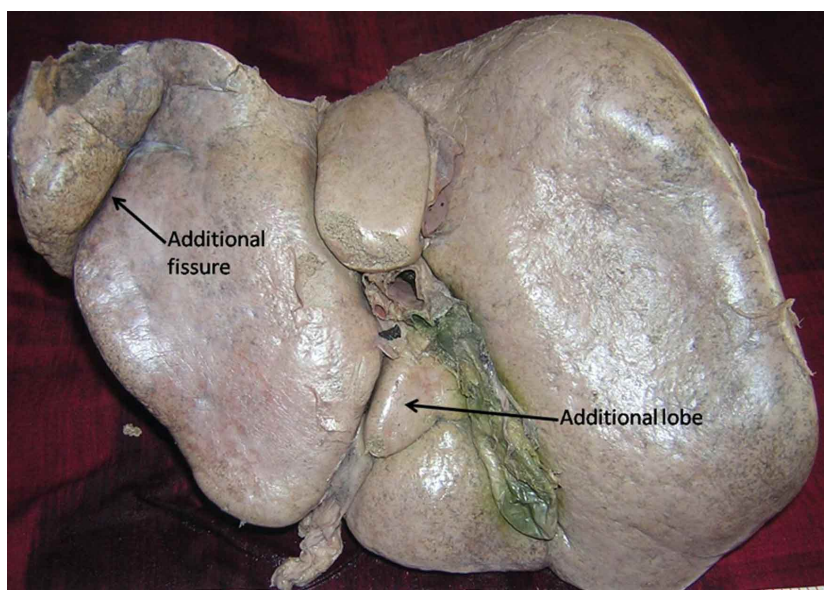

Fig. 1. Liver with an additional lobe and additional fissure.

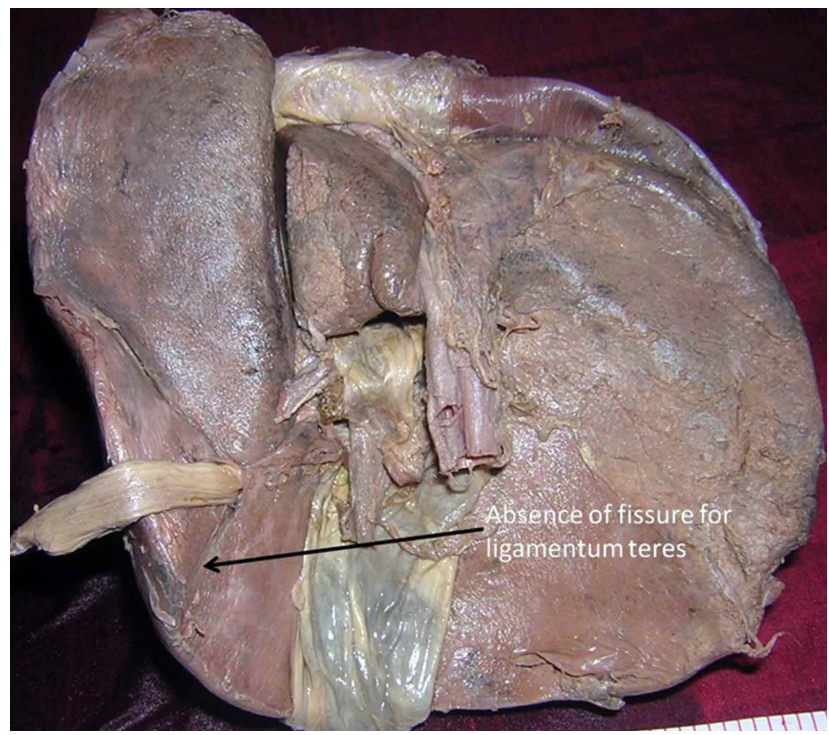

Fig. 2. Liver with absence of fissure for ligamentum venosum.

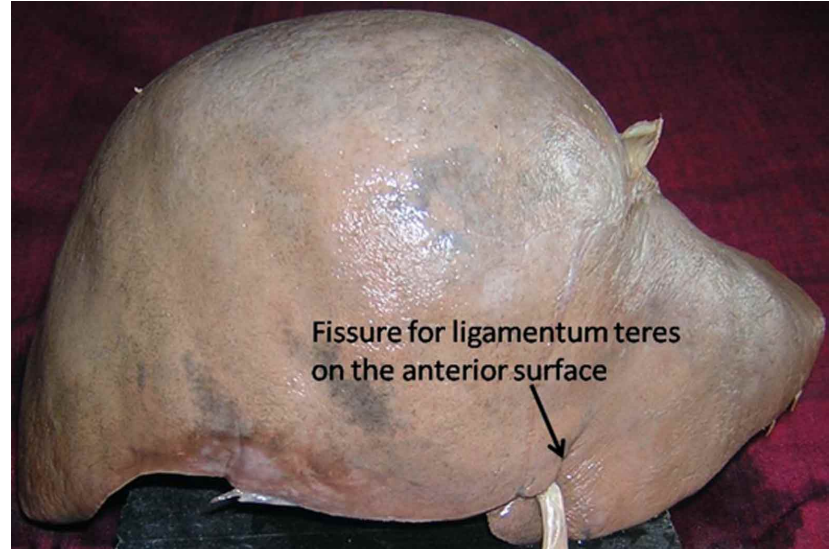

Fig. 3. Liver with fissure for ligamentum teres on the anterior surface.

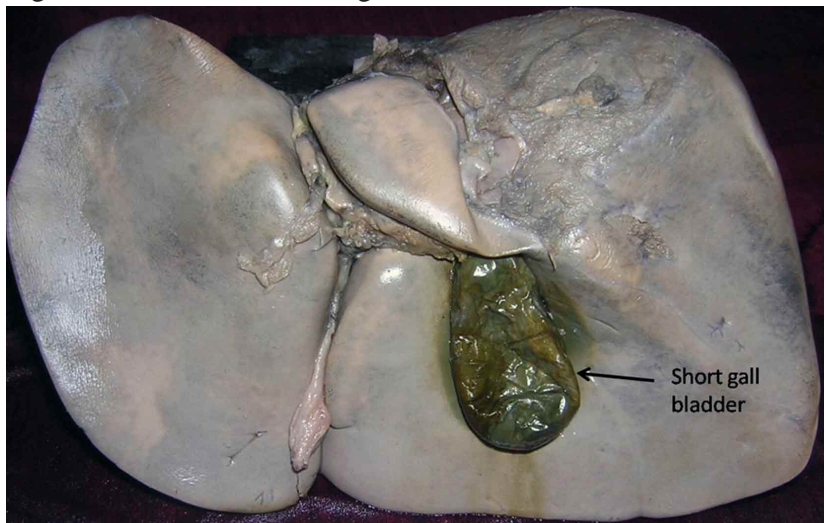

Fig.4. Liver with a short gall bladder.

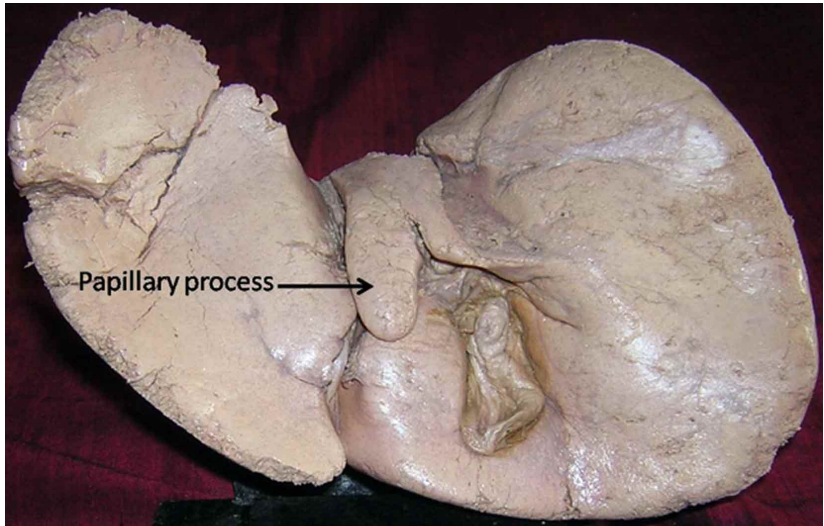

Fig. 5. Liver with a short gall bladder and a large papillary process.

Table I. The abnormalities of liver, the number of cases and percentage of their occurrence.

\begin{tabular}{lcc}
\hline Abnormality & $\mathbf{n}$ & $\mathbf{\%}$ \\
\hline Additional lobe & 5 & 9.09 \\
Additional fissure & 1 & 1.81 \\
Abnormal lobe & 1 & 1.81 \\
Enlarged papillary process & 1 & 1.81 \\
Short gall bladder & 10 & 18.18 \\
Absence of fissure for ligamentum teres & 1 & 1.81 \\
Fissure for lig. teres on the anterior surface & 1 & 1.81 \\
Extremely long left lobe & 1 & 1.81 \\
Flat liver & 1 & 1.81 \\
\hline
\end{tabular}




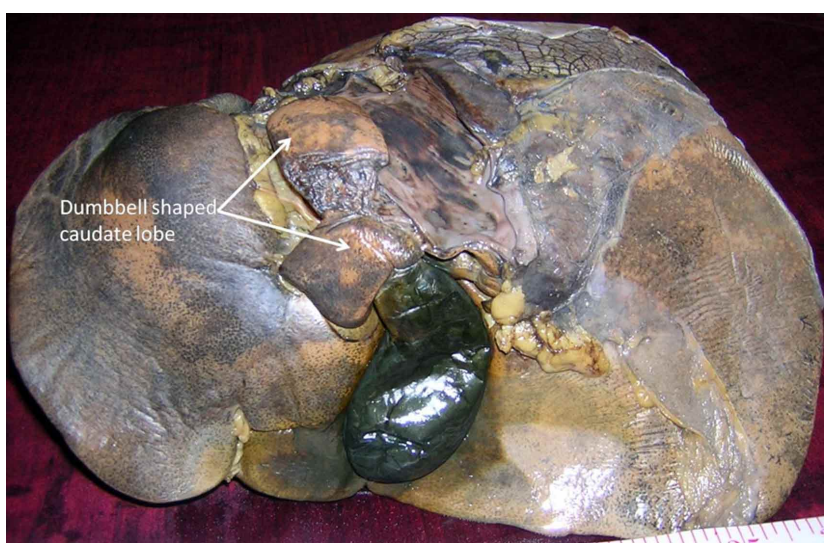

Fig. 6. Liver with a dumbbell shaped caudate lobe.

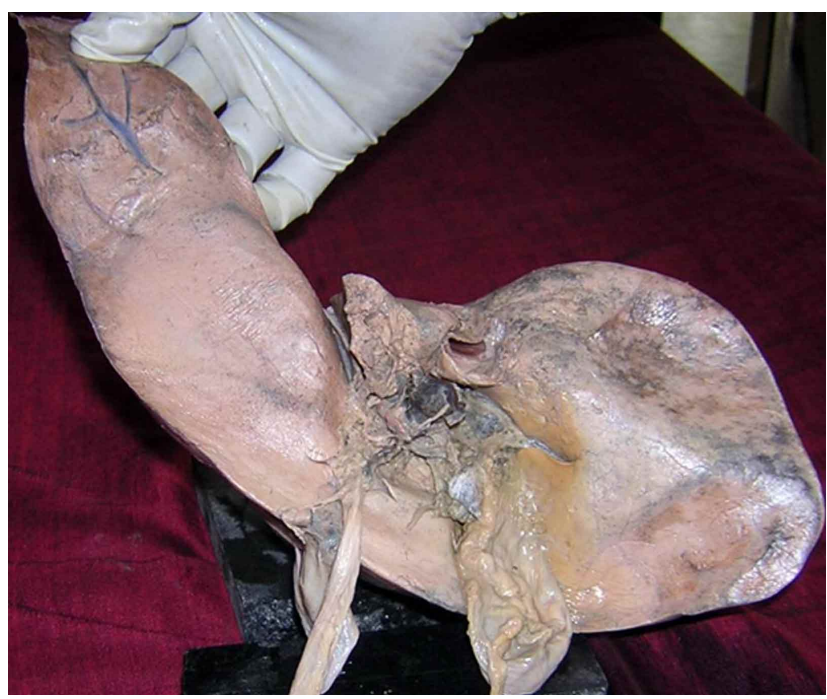

Fig. 7. Extremely long liver with a narrow and elongated left lobe.

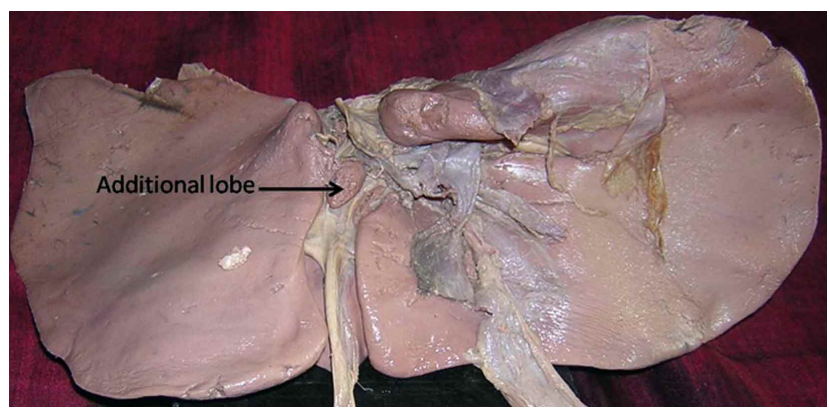

Fig. 8. Flat liver with additional lobe at the fissure for ligamentum venosum.

\section{DISCUSSION}

Liver may show abnormal or accessory lobes as anatomical variations. In the current study, 5 (9.09\%) livers had additional lobes. Abnormal lobes may lead to wrong diagnosis radiographically. Fitzgerald et al. (1993) have reported the presence of an additional lobe. The preoperative imaging of this lobe had lead to the misdiagnosis as a lesser omental lymphadenopathy. The patient with this variation had six weeks of intermittent upper abdominal pain. Presence of a large symptomatic accessory liver lobe was found in a woman aged 70 years by Llorente \& Dardik (1971). Pujari \& Deodhare (1976) have reported the presence of a symptomatic accessory lobe. The accessory lobes may herniate into the thorax through the diaphragm and cause serious problems (Feist \& Lasser, 1959), Joshi et al. (2009) did an extensive study on variations of the liver. They found notching along the inferior border of the caudate lobe in 18 percent of livers, a vertical fissure in 30 percent, and prominent papillary process in 32 percent. In our study only one liver (1.81\%) had a large papillary process.

Variations in the fissures are relatively rare. Accessory fissures may be present commonly on the anterosuperior surface (Macchi et al., 2003, 2005). The accessory fissures are the potential source of errors in diagnosis in imaging techniques (Auh et al., 1984). Collection of any fluid in accessory fissures may be mistaken for a cyst, liver abscess or intrahepatic hematoma. In our study only 1 liver (1.81\%) showed accessory fissure. We also noticed the absence of fissure for ligamentum teres and its occurrence on the anterior surface in $1.81 \%$ each cases. This variation of the fissure for ligamentum teres has not been reported yet.

Studies are lacking with regards to the overall shape and size of the liver. We saw one liver with extremely long left lobe and another liver which was flat like a pancake. There is no report on such livers in literature. These livers seemed to be healthy but the exact cause for their size and shape is not known to us.

The gall bladder is situated in the fossa for gall bladder on the inferior surface of the right anatomical lobe. Its fundus produces a cystic notch on the inferior border of the liver and projects beyond the inferior border to come in contact with the anterior abdominal wall. Due to this contact with the anterior abdominal wall, infections of gall bladder may infect the parietal peritoneum and this in turn will lead to the pain at the tip of right ninth costal cartilage where the fundus of gall bladder makes contact with the anterior abdominal wall. In our study, gall bladder was short in $18.18 \%$ of cases and failed to cross the inferior border of the liver. The fundus of the gall bladder was well within the limits of gall bladder fossa. Short gall bladders have not been reported in normal healthy livers. The gall bladder may be short or atrophic when there are abnormal peritoneal folds like cystohepatocolic folds are present (Pamidi et al., 2008; Nayak, 2009). Short gall bladders which hide in their fossa, may lead to confusions in imaging techniques and also in laparoscopic surgeries in the territory. 
In conclusion, this study highlights some of the variations in the lobes and fissures of the liver and position of the gall bladder. It may be useful for the imaging specialists and surgeons to prevent the possible misdiagnosis and the in planning the surgical procedures.

NAYAK, B. S. Estudio sobre las anomalías del hígado en cadáveres del sur de India. Int. J. Morphol., 31(2):658-661, 2013.

RESUMEN: El hígado es la glándula más grande del cuerpo y rara vez muestra variaciones en sus lóbulos y fisuras. Se estudiaron 55 hígados fijados en formalina para observar variaciones de su forma, lóbulos, fisuras y posición de la vesícula biliar. En el $60 \%$ de los casos, el hígado tuvo una forma normal. El 40\% restante mostró alguna variante. Se encontraron lóbulos adicionales en el 9,09\% de los casos. Una fisura adicional se encontró en $1,81 \%$ de los casos. La presencia de un lóbulo caudado en forma de mancuerna o reloj de arena, y la presencia de un gran proceso papilar se observó en el 1,81\% de los casos, respectivamente. En 1,81\% de los casos la fisura de ligamento redondo estaba ausente o situada en la superficie anterior del hígado. En 1,81\% de los casos el hígado era muy largo o plana, respectivamente. En el 18,18\% de los casos, la vesícula biliar fue corta y su fondo no se proyectó más allá del margen inferior del hígado. Estos resultados pueden ser útiles para cirujanos y radiólogos.

PALABRAS CLAVE: Hígado; Vesícula biliar; Variación; Lóbulos; Fisuras; Anormal.

\section{REFERENCES}

Auh, Y. H.; Rubenstein, W. A.; Zirinsky, K.; Kneeland, J. B.; Pardes, J. C.; Engel, I. A.; et al. Accessory fissures of the liver: CT and sonographic appearance. AJR Am. J. Roentgenol., 143(3):56572,1984

Fitzgerald, R.; Hale, M. \& Williams, C. R. Case report: accessory lobe of the liver mimicking lesser omental lymphadenopathy. Br. J. Radiol., 66(789):839-41, 1993.

Feist, J. H. \& Lasser, E. C. Identification of uncommon liver lobulations. J. Am. Med. Assoc., 169(16):1859-62, 1959.

Llorente, J. \& Dardik, H. Symptomatic accessory lobe of the liver associated with absence of the left lobe. Arch. Surg., 102(3):2213, 1971 .

Joshi, S. D.; Joshi, S. S. \& Athavale, S. A. Some interesting observations on the surface features of the liver and their clinical implications. Singapore Med. J., 50(7):715-9, 2009.

Macchi, V.; Feltrin, G.; Parenti, A. \& De Caro, R. Diaphragmatic sulci and portal fissures. J. Anat., 202(Pt 3):303-8, 2003.

Macchi, V.; Porzionato, A.; Parenti, A.; Macchi, C.; Newell, R. \& De Caro, R. Main accessory sulcus of the liver. Clin. Anat., 18(1):39-45, 2005.

Pamidi, N.; Nayak, S. \& Vollala, V. R. Cystogastrocolic fold and associated atrophy of the gallbladder. Singapore Med. J., 49(9):e250-1, 2008.

Pujari, B. D. \& Deodhare, S. G. Symptomatic accessory lobe of liver with a review of the literature. Postgrad. Med. J., 52(606):234-6, 1976.

Sahani, D. V. \& Kalva, S. P. Imaging the liver. Oncologist, 9(4):38597, 2004.
Nayak, S. B. Abnormal peritoneal fold connecting the greater omentum with the liver, gallbladder, right kidney and lesser omentum. Bratisl. Lek. Listy., 110(11):736-7, 2009.

Standring, S.; Ellis, H. \& Healy, J. C. Liver. In: Standring, S. (Ed.). Gray's Anatomy: The Anatomical Basis of Clinical Practice. 39th ed. London, Elsevier Churchill Livingstone, 2005. pp.121325.

Correspondence to:

Dr. Satheesha Nayak B.

Professor of Anatomy

Melaka Manipal Medical College (Manipal Campus)

International Centre for Health Sciences

Madhav Nagar

Manipal,

Udupi District

Karnataka State, 576104

INDIA

Phone: 91820 2922519, 919844009059

Email: nayaksathish@yahoo.com

Received : 08-02-2011

Accepted : 25-09-2012 